
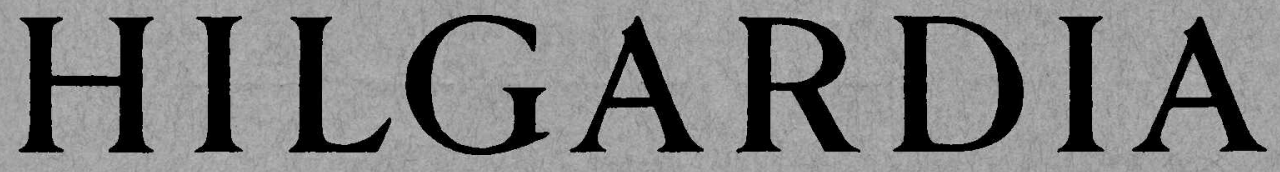

A Journal of Agricultural Science Publisbed by the California Agricultural Experiment Station

\title{
CONTENTS
}

LONGEVITY, OR LIFE HISTORIES, OF LEAFHOPPER SPECIES ON VIRUS-INFECTED AND ON HEALTHY PLANTS

HENRY H. P. SEVERIN

TRANSMISSION OF CALIFORNIA ASTER-YELLOWS VIRUS BY THE FIRST REPORTED LEAFHOPPER VECTOR IN GYPONINAE HENRY H. P. SEVERIN

TAXONOMY, DISTRIBUTION, AND FOOD PLANTS OF GYPONANA HASTA, A LEAFHOPPER VECTOR OF CALIFORNIA ASTER-YELLOWS VIRUS DWIGHT M. DELONG and HENRY H. P. SEVERIN 


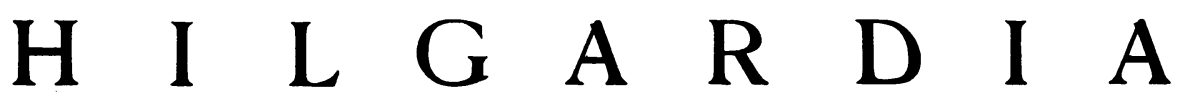

A Journal of Agricultural Science Published by

the California Agricultural Experiment Station

\section{LONGEVITY, OR LIFE HISTORIES, OF LEAF- HOPPER SPECIES ON VIRUS-INFECTED AND ON HEALTHY PLANTS ${ }^{1}$}

\author{
HENRY H. P. SEVERIN ${ }^{2}$
}

\section{INTRODUCTION}

IN DIScussing the effect of the virus on the insect vector, Leach $(1940)^{3}$ has suggested that the question of whether a virus-infected plant is a more favorable host plant than a healthy plant, has been given little attention in virus studies.

Carter (1939), working with yellow-spot of pineapple, found that infected weeds of Emilia sonchifolia DC maintain, on an average, higher populations of onion thrips, Thrips tabaci Lind., than do healthy plants. He concluded that diseased plants may persist for a longer time, with a mass of curled leaves affording satisfactory shelter for the vector, than do healthy plants which grow rapidly, mature, and die.

It is a well-known fact among entomologists who have carried on field investigations with the beet leafhopper, Eutettix tenellus (Baker), that when sugar beets are harvested, the adults fly to other food plants, and a high mortality occurs with the change in host plants. During the 1925 outbreak of the pest, and after the beet tops became dry, enormous numbers of leafhoppers were found in bean fields (Severin and Henderson, 1928), and dead adults were commonly found with their mouth parts inserted in the bean leaves. Tomato plants are favorable host plants of the curly-top virus, but are unfavorable food plants of the beet leafhopper. The decrease in longevity of the males and females on tomato plants has been discussed in a previous paper (Severin, 1928).

During the past seventeen years, 9 leafhopper species have been reported by the author (Severin, 1929, 1934, 1945) to be capable of transmitting the California aster-yellows virus. During the course of an investigation on the longevity of noninfective short-winged Macrosteles divisus (Uhler) and longwinged aster leafhoppers-a biological race of the same species (Severin,

\footnotetext{
${ }^{1}$ Received for publication November 15, 1945.

2 Entomologist in the Experiment Station.

"See "Literature Cited" at the end of the paper for complete citations, referred to in the text by author and date of publication.
} 
1940) which had completed their nymphal stages on mildew-resistant Sacramento barley nonsusceptible to the California aster yellows-it was found that low populations of adults of the short-winged leafhoppers were reared, whereas, the long-winged died on healthy celery after the first molt. It was also demonstrated that when both vectors were allowed to reproduce on celery infected with the virus, high populations of adult short-winged aster leafhoppers and low populations of adult long-winged forms were obtained.

Among a large number of newly discovered leafhopper vectors, some species reproduced on both healthy and infected celery; other species multiplied on diseased celery and asters only, and died when transferred to healthy celery and asters; and still other species lived long enough to complete the latent period of the virus but failed to reproduce, and also died when transferred to healthy celery or asters.

Kunkel (1926) found that the latent period of the New York aster-yellows virus in the short-winged aster leafhoppers, using 30 to 100 nymphs or adults in many tests, varied between 10 to 19 days at $70^{\circ} \mathrm{F}$. Kunkel (1932) also reported that the latent period of the California aster-yellows virus in the short-winged aster leafhopper, using 30 to 125 nymphs, varied from 19 to 26 days, with an average of 23 days. The latent period of the virus in Texananus lathropi Baker varied from 7 to 33 days, in T. latipex DeLong from 8 to 37 days, and in T. spatulatus Van Duzee from 6 to 35 days, as determined by Severin (1945). Any species of leafhopper which failed to survive on diseased celery or asters for at least 1 week could not be tested as a possible vector, since the latent period of the virus was not completed in the insects.

The present paper deals with the longevity of 9 species of leafhoppers on virus-infected and healthy plants, 5 of which have been previously reported as vectors of the virus (Severin, 1929, 1934, 1945). Another aspect of the problem was to compare the total duration of the nymphal stages of 2 species of phlepsid leafhoppers on healthy and diseased celery plants, and of the beet leafhopper on healthy and curly-top sugar beets.

\section{METHODS}

The production of noninfective short-winged and long-winged aster leafhoppers has been described in previous papers (Severin 1929, 1942). The method of obtaining noninfective Texananus lathropi, T. latipex, and Cloanthanus irroratus (Van Duzee) was similar to that reported for the beet leafhopper (Severin, 1921). The technique used in obtaining noninfective populations of T. spatulatus (Van Duzee) has been described in a previous paper (Severin, 1945). In determining the longevity of species of leafhoppers, recently molted adults were used, reared from high populations of last instar nymphs. 


\section{LONGEVITY OF SPECIES OF LEAFHOPPERS ON VIRUS- INFECTED AND ON HEALTHY PLANTS}

\section{TEXANANUS DENTICULUS OSBORN AND LATHROP}

This leafhopper (plate 1, $G, H$ ) completed the nymphal stages on infected celery, but died on healthy, control celery plants. Fifty males and 50 females were kept singly, each on a healthy celery plant, and a daily record was taken of the mortality of the adults. The longevity of the males ranged from 2 to 20 days, with an average of only 6.9 days; females, from 2 to 33 days, with an average of only 8.4 days.

\section{TEXaNaNUS PERGRadUS DeLONG}

This leafhopper vector (Severin, 1945) completed the nymphal stages on experimentally and naturally infected celery, but when transferred to healthy celery the adults died. In testing the efficiency of this vector in transmitting the virus, 50 males and 50 females were kept singly, each on a healthy celery plant during adult life. The longevity of the males ranged from 3 to 8 days, with an average of only 4.8 days; females, from 2 to 12 days, with an average of only 6.7 days.

In another test, 2 lots of 10 recently molted, infective males and females were kept singly, each on a healthy celery plant, and the same number of adults were kept singly on diseased celery plants. On healthy celery, the longevity of 10 males ranged from 3 to 9 days, with an average of only 6.1 days; females, 3 to 22 days, with an average of only 11.6 days.

On infected celery, 10 males and 10 females were alive at the end of 24 days ; then equal numbers of males and females were combined on experimentally and naturally infected celery and high populations of adults were reared on both.

\section{TEXANANUS SPATULATUS VAN DUZEE}

A comparison was made of the longevity of each leafhopper which transmitted the virus to celery (Severin, 1945) with each adult which failed and, hence, was feeding continuously on healthy celery. The longevity of 34 males which induced the disease ranged from 4 to 144 days, with an average of 45.6 days; and of the 29 females which caused infections, 4 to 198 days, with an average of 51.3 days. The average adult life of 66 males which failed to transmit the virus was 17.9 days; and of 71 females, 20.3 days. Evidently a virusinfected plant prolonged the life of this leafhopper even before symptoms of the disease developed.

This leafhopper completed the nymphal stages on diseased asters. Each of 50 recently molted males and 50 females, which completed the nymphal stages on infected asters, was transferred to a healthy aster, and a daily record of the mortality was taken. The males lived from 1 to 23 days, with an average of only 3.1 days; females, 1 to 28 days, with an average of only 6.3 days. The life cycle was not completed on healthy asters.

\section{CLOANTHANUS IRRORATUS (VAN DUZEE)}

The life cycle of this leafhopper was completed on diseased asters. The longevity of 50 males, kept singly, each on a healthy aster, ranged from 1 to 11 
days, with an average of only 4.1 days ; and of 50 females from 2 to 25 days, with an average of only 10.2 days. The leafhoppers did not complete their life history on healthy asters.

\section{EUSCELES MACULIPENIS DELONG}

The nymphal stages of this leafhopper were completed on diseased asters. The longevity of 50 males on healthy asters ranged from 1 to 35 days, with an average of only 3.4 days; 50 females, 1 to 24 days, with an average of only 3.5 days. This leafhopper also failed to complete the life cycle on healthy asters.

\section{GEMINATE LEAFHOPPER, COLLADONUS GEMINATUS (VAN DUZEE)}

As reported in a previous paper (Severin, 1934), the geminate leafhopper was collected on large asters under natural conditions, but a high mortality occurred on small asters in the greenhouse. It was found that adults which were fed on small healthy asters died within a week. The longevity of the last surviving adult of 11 lots of 50 recently molted adults on large healthy asters, ranged from 26 to 123 days, with an average of 84.5 days. Sometimes nymphs completed the nymphal stages when fed on large healthy asters. Nymphs reached the adult stage on diseased asters.

\section{MOUNTAIN LEAFHOPPER, COLLADONUS MONTANUS (VAN DUZEE)}

The nymphal stages of the mountain leafhopper were completed on infected asters. The adult life on small asters ranged from 2 to 15 days, with an average of only 4.3 days.

\section{IDIODONUS KIRKALDYI (BAIL)}

There are numerous leafhopper species which live on diseased celery and asters, but when transferred to healthy plants they die. One illustration will suffice. No attempt has been made to rear Idiodonus kirkaldyi on coast sagebrush, Artemesia california, its natural host plant. One lot of 4 adults was kept on infected celery for 66 days, whereas the longevity of 10 males on healthy celery ranged from 1 to 10 days, with an average of only 3.2 days; females, 1 to 6 days, with an average of only 3.4 days. On healthy asters the adult life of the males ranged from 1 to 10 days, with an average of only 8.6 days ; females, 1 to 32 days, with an average of only 7.8 days.

\section{COMPARISON OF DURATION OF NYMPHAL STAGES ON HEALTHY AND DISEASED PLANTS}

\section{TEXANANUS LATHROPI BAKER}

A comparison was made of the interval or period between molts (stages, or stadia-not to be confused with longevity of adults) and the total duration of the nymphal stages of Texananus lathropi (plate $1, A, B, C, D, E, F, I$ ) reared singly on healthy and diseased celery plants (table 1 ). In the first experiment, the average total duration of the nymphal stages of the males was 69 days on healthy celery and 51.6, or 7.4 days less, on infected celery ; and of the females, 63 days on healthy celery and 60.9, or 2.1 days less, on diseased celery.

In the second experiment, 8 males reared on healthy celery required an average of 51.7 days and 1 male, 52 days on infected celery, or 0.3 days longer on healthy celery. 


\section{TABLE 1}

Duration of Stadia Texananus lathropi on Healthy and on Infected Celery Plants (Expressed as number of days between molts)

\begin{tabular}{l|c|c|c|c|c|c|c|}
\hline \hline & $\begin{array}{c}\text { First } \\
\text { instar }\end{array}$ & $\begin{array}{c}\text { Second } \\
\text { instar }\end{array}$ & $\begin{array}{c}\text { Third } \\
\text { instar }\end{array}$ & $\begin{array}{c}\text { Fourth } \\
\text { instar }\end{array}$ & $\begin{array}{c}\text { Fifth } \\
\text { instar }\end{array}$ & $\begin{array}{c}\text { Sixth } \\
\text { instar }\end{array}$ & Total \\
\hline
\end{tabular}

Four males hatched on May 1, and reared on healthy celery plants (first experiment)

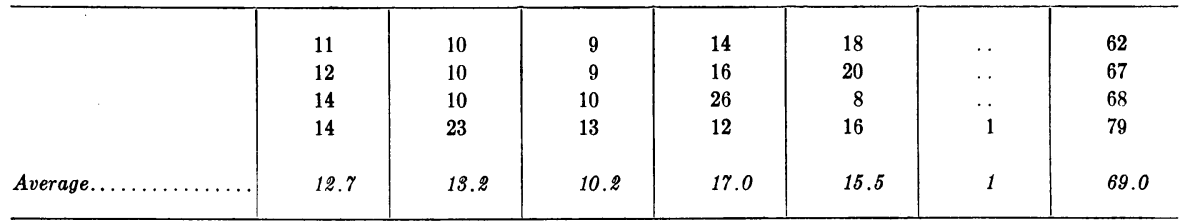

Five males hatched on May 1, and reared on infected celery plants (first experiment)

\begin{tabular}{|c|c|c|c|c|c|c|c|}
\hline & 12 & 5 & 9 & 9 & 12 & .. & 47 \\
\hline & 12 & 4 & 8 & 10 & 14 & .. & 48 \\
\hline & 12 & 5 & 8 & 9 & 14 & $\ldots$ & 48 \\
\hline & 12 & 10 & 9 & 16 & 20 & .. & 67 \\
\hline
\end{tabular}

Six females hatched on May 1, and reared on healthy celery plants (first experiment)

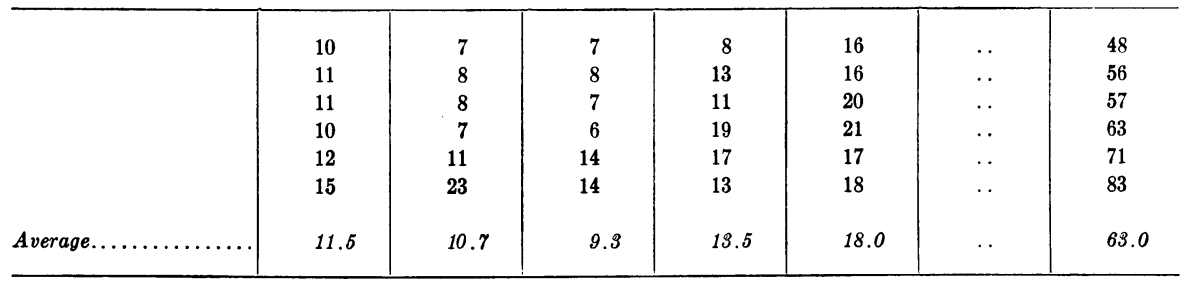

Seven females hatched on May 1, and reared on infected celery plants (first experiment)

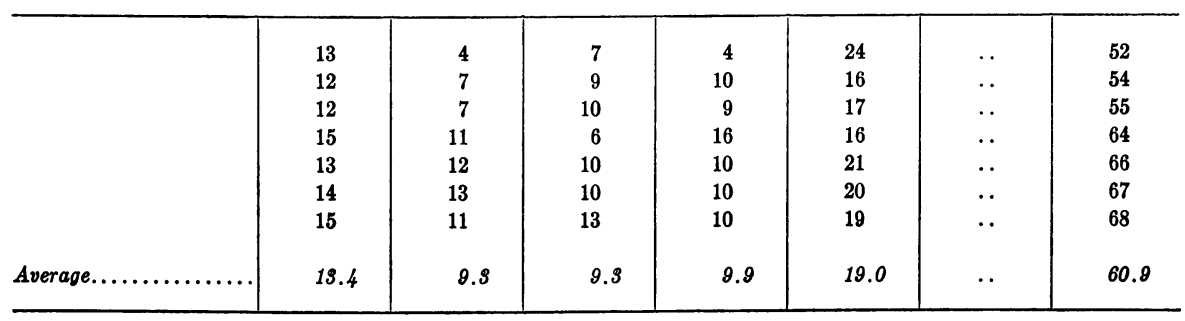

Eight males hatched on August 30, and reared on healthy celery plants (second experiment)

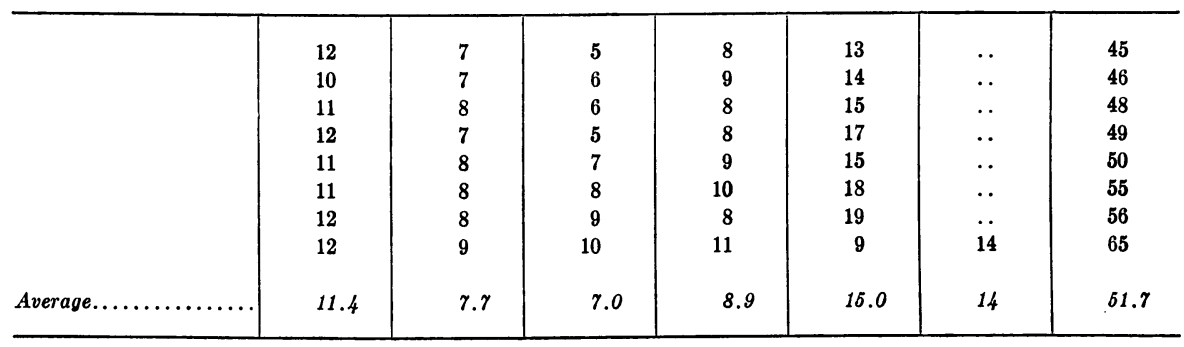


TABLE 1 (Continued)

\begin{tabular}{l|c|c|c|c|c|c|c}
\hline \hline & $\begin{array}{c}\text { First } \\
\text { instar }\end{array}$ & $\begin{array}{c}\text { Second } \\
\text { instar }\end{array}$ & $\begin{array}{l}\text { Third } \\
\text { instar }\end{array}$ & $\begin{array}{c}\text { Fourth } \\
\text { instar }\end{array}$ & $\begin{array}{c}\text { Fifth } \\
\text { instar }\end{array}$ & $\begin{array}{c}\text { Sixth } \\
\text { instar }\end{array}$ & Total \\
\hline
\end{tabular}

One male hatched on August 30, and reared on infected celery plant (second experiment)

\begin{tabular}{l|l|l|l|l|l|l|l}
\hline & 12 & 9 & 7 & 6 & 18 & & $\ldots$ \\
\hline
\end{tabular}

Three females hatched on August 30, and reared on healthy celery plants (third experiment)

\begin{tabular}{l|c|c|r|r|r|r|r}
\hline & 12 & 7 & 5 & 9 & 18 & $\ldots$ & 51 \\
& 12 & 8 & 7 & 9 & 19 & $\ldots$ & 55 \\
& 12 & 11 & 11 & 12 & 23 &.. & 69 \\
\hline & 12.0 & 8.7 & 7.7 & 10.0 & 20.0 & $\ldots$ & 58.3 \\
\hline
\end{tabular}

Eleven females hatched on August 30, and reared on infected celery plants (third experiment)

\begin{tabular}{|c|c|c|c|c|c|c|c|}
\hline & 10 & 8 & 6 & 9 & 14 & .. & 47 \\
\hline & 11 & 7 & 6 & 9 & 15 & .. & 48 \\
\hline & 10 & 7 & 6 & 9 & 16 & .. & 48 \\
\hline & 12 & 6 & 5 & 3 & 16 & . & 42 \\
\hline & 10 & 8 & 6 & 10 & 15 & .. & 49 \\
\hline & 12 & 7 & 8 & 8 & 15 & $\ldots$ & 50 \\
\hline & 10 & 7 & 7 & 10 & 17 & $\ldots$ & 51 \\
\hline & 12 & 7 & 8 & 7 & 17 & .. & 51 \\
\hline & 13 & 8 & 7 & 11 & 10 & $\mathbf{5}$ & 54 \\
\hline & 11 & 8 & 6 & 10 & 20 & .. & $\mathbf{5 5}$ \\
\hline & 11 & 7 & 6 & 11 & 24 & .. & 59 \\
\hline Average............... & 11.1 & 7.5 & 6.5 & 8.8 & 16.3 & b & 50.4 \\
\hline
\end{tabular}

In the third experiment, the average total duration of the nymphal stages of the females was 58.3 days on healthy celery and 50.4, or 7.9 days less, on diseased celery.

Two nymphs reared on healthy celery passed through six molts ; all others, whether on healthy or diseased plants, molted five times.

The life history of Texananus lathropi was repeated, but only the total duration of the nymphal stages was determined on healthy and diseased celery plants. The average total duration of the nymphal stages on healthy versus diseased celery plants (table 2) for males was 40.7 days as compared with 38.6 days, and for females, 46.0 days as compared with 40.2 days, demonstrating that the average total duration of the nymphal stages is less on diseased plants.

A statistical analysis of the data on the duration of the nymphal stages of each adult reared on healthy and diseased plants showed no significance.

A high mortality of nymphs occurred when reared on healthy celery plants. A nymphal stage may be greatly prolonged, sometimes a month or longer, but such nymphs die before molting again. Sometimes nymphs die in the process of molting. The mortality of the nymphs was determined with 80 nymphs which hatched on 3 successive days and were placed on 3 healthy celery plants. The nymphs were counted 38 days after hatching and 56 were alive. Fortyfour, or 55.0 per cent, of the nymphs reached the adult stage. 
A comparison was made of the number of adults reared on healthy and infected celery plants. After their last molt, 10 males and 10 females were confined, 1 pair in each cage which contained either a healthy or diseased celery plant. The number of adults reared from each pair was as follows: healthy celery, $51,63,64,113$, and 158 , or an average of 97 ; infected celery, 229, 231, 345,369 , and 395 , or an average of 341 .

TABLE 2

Total Duration of Nymphal Stages of Texananus lathropi Hatched on April 26, Reared on Healthy aNd on Infected Celery Plants

\begin{tabular}{|c|c|c|c|c|}
\hline & $\begin{array}{l}\text { Number of noninfective } \\
\text { males reared }\end{array}$ & $\begin{array}{l}\text { Total duration } \\
\text { of nymphal stages } \\
\text { of males, } \\
\text { days }\end{array}$ & $\begin{array}{l}\text { Number of noninfective } \\
\text { females reared }\end{array}$ & $\begin{array}{l}\text { Total duration } \\
\text { of nymphal stages } \\
\text { of females, } \\
\text { days }\end{array}$ \\
\hline \multicolumn{5}{|c|}{ Reared on healthy celery plants } \\
\hline & 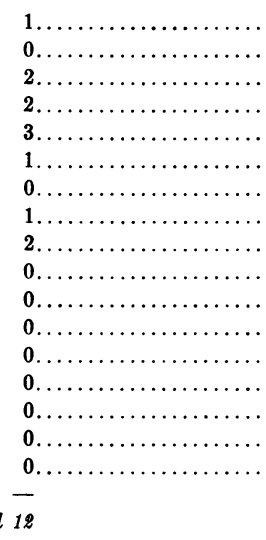 & $\begin{array}{cc}34 \\
. . \\
39 \\
40 \\
41 \\
42 \\
. . \\
44 \\
45 \\
. . \\
. . \\
. . \\
. . \\
. . \\
. . \\
. . \\
. . \\
\text { Average } & 40.7\end{array}$ & 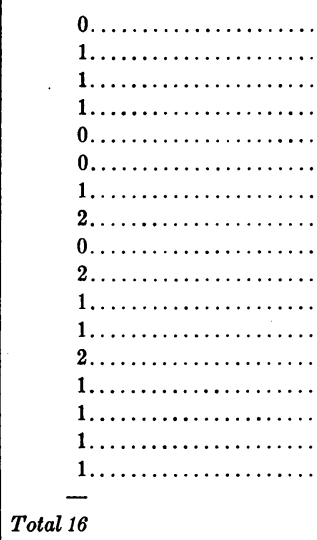 & 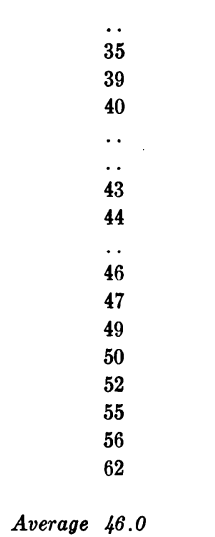 \\
\hline \multicolumn{5}{|c|}{ Reared on infected celery plants } \\
\hline Total & 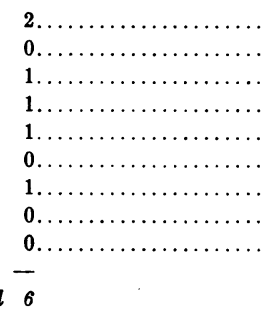 & $\begin{array}{c}34 \\
. . \\
38 \\
39 \\
40 \\
. \\
42 \\
. . \\
\because . \\
\text { Average } 38.6\end{array}$ & 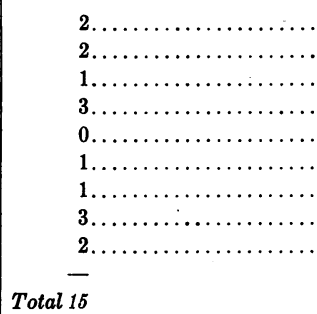 & 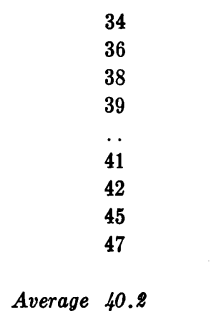 \\
\hline
\end{tabular}

\section{TEXANANUS SPATULATUS VAN DUZEE}

A comparison was made of the duration of periods between molts of Texananus spatulatus reared on healthy celery with those of leafhoppers on celery infected with aster yellows; and the same comparison was made with rearing on healthy sugar beets and on curly-top beets (table 3), although this leafhopper is not a vector of the curly-top virus.

The average total duration of the nymphal stages of the males was 112 
TABLE 3

Duration of Stadia of Texananus spatulatus Reared on Celery Infected with Aster Yellows, on Sugar Beets Infected with Curly Top, and on Healthy Plants

\begin{tabular}{|c|c|c|c|c|c|c|c|}
\hline \multirow{2}{*}{ Date hatched } & \multicolumn{7}{|c|}{ Duration of stadia, days } \\
\hline & $\begin{array}{c}\text { First } \\
\text { instar }\end{array}$ & $\begin{array}{l}\text { Second } \\
\text { instar }\end{array}$ & $\begin{array}{l}\text { Third } \\
\text { instar }\end{array}$ & $\begin{array}{l}\text { Fourth } \\
\text { instar }\end{array}$ & $\begin{array}{l}\text { Fifth } \\
\text { instar }\end{array}$ & $\begin{array}{l}\text { Sixth } \\
\text { instar }\end{array}$ & Total \\
\hline \multicolumn{8}{|c|}{ Males reared on healthy celery plants } \\
\hline September 30. & 12 & 7 & 5 & 9 & 19 & . & 52 \\
\hline September 25 . & 10 & 10 & 14 & 19 & 33 & .. & 86 \\
\hline September 25 . & 10 & 10 & 8 & 45 & 14 & .. & 87 \\
\hline September 24 & 10 & 11 & 8 & 43 & 16 & $\cdots$ & 88 \\
\hline September 24 & 10 & 11 & 10 & 58 & 33 & .. & 112 \\
\hline September 2. & 11 & 7 & 6 & 11 & 62 & 18 & 115 \\
\hline August $30 \ldots$ & 30 & 13 & 9 & 59 & 21 & . & 132 \\
\hline Average... & 13.3 & 9.9 & 8.6 & 34.7 & 26.9 & 18.0 & 112 \\
\hline
\end{tabular}

Males reared on infected celery plants

\begin{tabular}{|c|c|c|c|c|c|c|c|}
\hline September 25 . . & 6 & 14 & 9 & 38 & 17 & . & 84 \\
\hline September $25 \ldots$ & 10 & 10 & 17 & 53 & 21 & . & 111 \\
\hline September $24 \ldots \ldots \ldots \ldots \ldots \ldots \ldots$ & 9 & 12 & 11 & 55 & 26 & . & 113 \\
\hline Average $\ldots \ldots \ldots \ldots \ldots$ & 8.3 & 12.0 & 12.3 & 48.7 & 21.3 & . & 102.7 \\
\hline
\end{tabular}

Females reared on healthy celery plants

\begin{tabular}{|c|c|c|c|c|c|c|c|}
\hline September $25 \ldots \ldots \ldots \ldots \ldots \ldots \ldots$ & 10 & 10 & 11 & 55 & 16 & . & 102 \\
\hline September $25 . \ldots \ldots \ldots \ldots \ldots \ldots \ldots$ & 12 & 9 & 29 & 44 & 18 & . & 112 \\
\hline Average.......... & 11.0 & 9.5 & 20.0 & 49.5 & 17.0 & . & 107 \\
\hline
\end{tabular}

Females reared on infected celery plants

\begin{tabular}{|c|c|c|c|c|c|c|c|}
\hline September $25 \ldots \ldots \ldots \ldots \ldots \ldots \ldots$ & 9 & 11 & 10 & 46 & 17 & $\ldots$ & 93 \\
\hline September 24 . & 11 & 11 & 15 & 49 & 14 & . & 100 \\
\hline September $26 \ldots \ldots \ldots \ldots \ldots$ & 11 & 11 & 11 & 42 & 30 & . & 105 \\
\hline September $28 \ldots \ldots \ldots \ldots \ldots$ & 6 & 11 & 14 & 65 & 18 & $\cdots$ & 114 \\
\hline September $26 \ldots \ldots \ldots \ldots \ldots \ldots$ & 11 & 10 & 14 & 61 & 19 & $\cdots$ & 115 \\
\hline
\end{tabular}

Male reared on healthy sugar beet

\begin{tabular}{|c|c|c|c|c|c|c|c|}
\hline September $25 \ldots \ldots \ldots \ldots \ldots \ldots \ldots$ & 9 & 12 & 12 & 59 & 19 & . & 111 \\
\hline \multicolumn{8}{|c|}{ Males reared on infected sugar beets } \\
\hline September $25 \ldots$ & 9 & 11 & 9 & 47 & 15 & .. & 91 \\
\hline September 25. & 9 & 11 & 11 & 48 & 17 & .. & 96 \\
\hline Average..... & 9.0 & 11.0 & 10.0 & 47.5 & 16.0 & . & 93.5 \\
\hline
\end{tabular}


TABLE 3 (Continued)

\begin{tabular}{|c|c|c|c|c|c|c|c|}
\hline \multirow{2}{*}{ Date hatched } & \multicolumn{7}{|c|}{ Duration of stadia, days } \\
\hline & $\underset{\text { instar }}{\text { First }}$ & $\begin{array}{l}\text { Second } \\
\text { instar }\end{array}$ & $\begin{array}{l}\text { Third } \\
\text { instar }\end{array}$ & $\begin{array}{c}\text { Fourth } \\
\text { instar }\end{array}$ & $\begin{array}{c}\text { Fifth } \\
\text { instar }\end{array}$ & $\begin{array}{l}\text { Sixth } \\
\text { instar }\end{array}$ & Total \\
\hline \multicolumn{8}{|c|}{ Female reared on healthy sugar beet } \\
\hline September $25 \ldots$. & 9 & 10 & 13 & 52 & 8 & 19 & 111 \\
\hline \multicolumn{8}{|c|}{ Females reared on infected sugar beets } \\
\hline September $25 \ldots$ & 9 & 11 & 10 & 38 & 17 . & . & 85 \\
\hline September $25 \ldots$ & 9 & 11 & 11 & 40 & 15 & .. & 86 \\
\hline September $25 \ldots$ & 9 & 11 & 11 & 47 & 17 & . & 95 \\
\hline September $25 \ldots$. & 9 & 11 & 14 & 62 & 16 & .. & 112 \\
\hline Average..... & 9.0 & 11.0 & 11.5 & 45.4 & 16.2 & .. & 94.6 \\
\hline
\end{tabular}

days on healthy celery and 102.7, or 9.3 days less, on infected celery; and of the females, 107 days on healthy celery and 105.4, or 1.6 days less, on diseased celery.

The total duration of the nymphal stages on healthy versus curly-top beets (table 3 ) for 1 male was 111 days as compared with an average of 93.5 days for 2 males, and for 1 female, 111 days, compared with an average of 94.5 days for 4 females. These results demonstrate that the average total duration of the nymphal stages is less on diseased plants, even though only 8 adults were reared.

Two nymphs passed through six molts, all others through five.

A statistical analysis of the data on the duration of the nymphal stages of each adult reared on healthy and diseased plants showed no significance.

\section{BEET LEAFHOPPER, EUTETTIX TENELIUS (BAKER)}

A comparison was made of the total duration of the nymphal stages of the beet leafhopper, Eutettix tenellus, reared on healthy and on curly-top sugar beets (table 4). In three experiments the males required 4.4,10.3, and 1 days longer on curly-top than on healthy beets; and the females, 1.1, 1.6, and 10.2 days longer. There was no evidence to show that the total duration of the nymphal stages is shorter on curly-top beets than on healthy ones.

\section{SUMMARY}

Evidence is presented in this paper that 9 species of leafhopper vectors tested completed the nymphal stages on celery or asters infected with the California aster-yellows virus, but that the adults died when transferred to healthy celery or to asters. The longevity of single males and females of Texananus spatulatus was longer on infected celery before symptoms developed than on healthy celery.

The average total duration of the nymphal stages of Texananus lathropi was less on infected than on healthy celery, with one exception : where small num- 
TABLE 4

Total Duration of Nymphal Stages of Eutettix tenellus Reared on Healthy and on CuRLY-TOP SUgAR BEETS

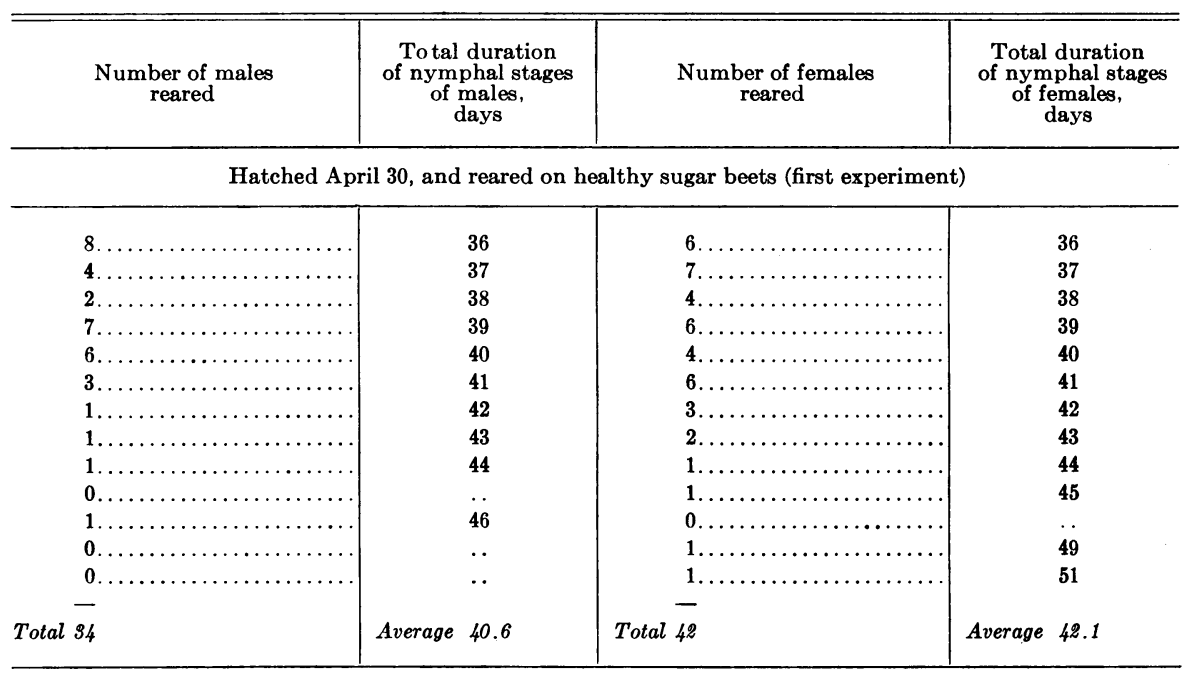

Hatched April 30, and reared on curly-top sugar beets (first experiment)

\begin{tabular}{|c|c|c|c|}
\hline $1 \ldots \ldots \ldots \ldots \ldots \ldots \ldots$ & 37 & $0 \ldots \ldots \ldots \ldots \ldots \ldots \ldots$ & 37 \\
\hline $0 \ldots \ldots \ldots \ldots \ldots \ldots \ldots \ldots$ & 38 & $1 \ldots \ldots \ldots \ldots \ldots \ldots \ldots$ & 38 \\
\hline $1 \ldots \ldots \ldots \ldots \ldots \ldots \ldots$, & 39 & $0, \ldots \ldots \ldots \ldots \ldots \ldots \ldots$ & 39 \\
\hline $2 \ldots \ldots \ldots \ldots \ldots \ldots \ldots \ldots$ & 41 & $3 \ldots \ldots \ldots \ldots \ldots \ldots \ldots$ & 41 \\
\hline $6 \ldots \ldots \ldots \ldots \ldots \ldots \ldots \ldots$ & 42 & $6 \ldots \ldots \ldots \ldots \ldots \ldots \ldots$ & 42 \\
\hline $1 \ldots \ldots \ldots \ldots \ldots \ldots \ldots \ldots \ldots$ & 45 & $1 \ldots \ldots \ldots \ldots \ldots \ldots \ldots \ldots$ & 45 \\
\hline $3 \ldots \ldots \ldots \ldots \ldots \ldots \ldots$ & 48 & $1 \ldots \ldots \ldots \ldots \ldots$ & 48 \\
\hline $2 \ldots \ldots \ldots \ldots \ldots \ldots \ldots \ldots \ldots$ & 49 & $1 \ldots \ldots \ldots \ldots \ldots \ldots$ & 49 \\
\hline $1 \ldots \ldots \ldots \ldots \ldots \ldots \ldots \ldots \ldots$ & 52 & $0 \ldots \ldots \ldots \ldots \ldots \ldots \ldots \ldots \ldots$ & . \\
\hline $1 \ldots \ldots \ldots \ldots \ldots \ldots \ldots \ldots$ & 54 & $0 \ldots \ldots \ldots \ldots \ldots \ldots \ldots$ & . \\
\hline Total 24 & Average 45.0 & Total 23 & Average 43.2 \\
\hline
\end{tabular}

Hatched May 1, and reared on healthy sugar beets (second experiment)

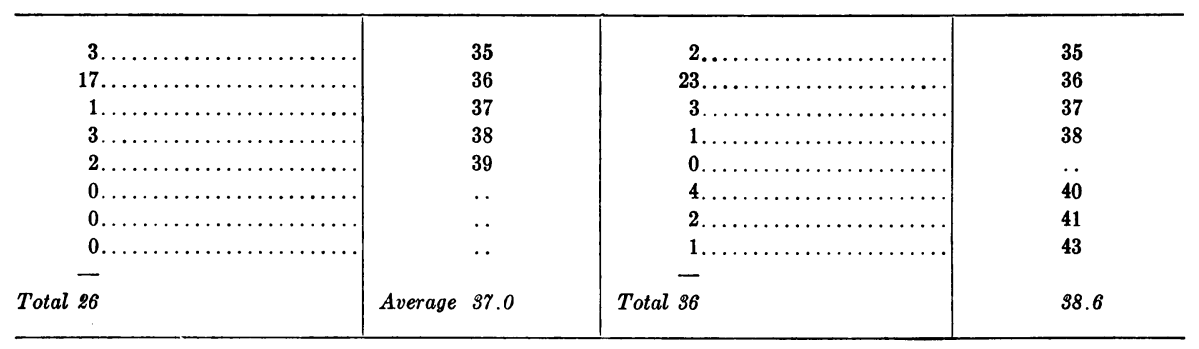


TABLE 4 (Continued)

\begin{tabular}{|c|c|c|c|}
\hline $\begin{array}{l}\text { Number of males } \\
\text { reared }\end{array}$ & $\begin{array}{c}\text { Total duration } \\
\text { of nymphal stages } \\
\text { of males. } \\
\text { days }\end{array}$ & $\begin{array}{l}\text { Number of females } \\
\text { reared }\end{array}$ & $\begin{array}{c}\text { Total duration } \\
\text { of nymphal stages } \\
\text { of females, } \\
\text { days }\end{array}$ \\
\hline \multicolumn{4}{|c|}{ Hatched May 1, and reared on curly-top sugar beets (second experiment) } \\
\hline
\end{tabular}

Hatched May 3, and reared on healthy sugar beets (third experiment)

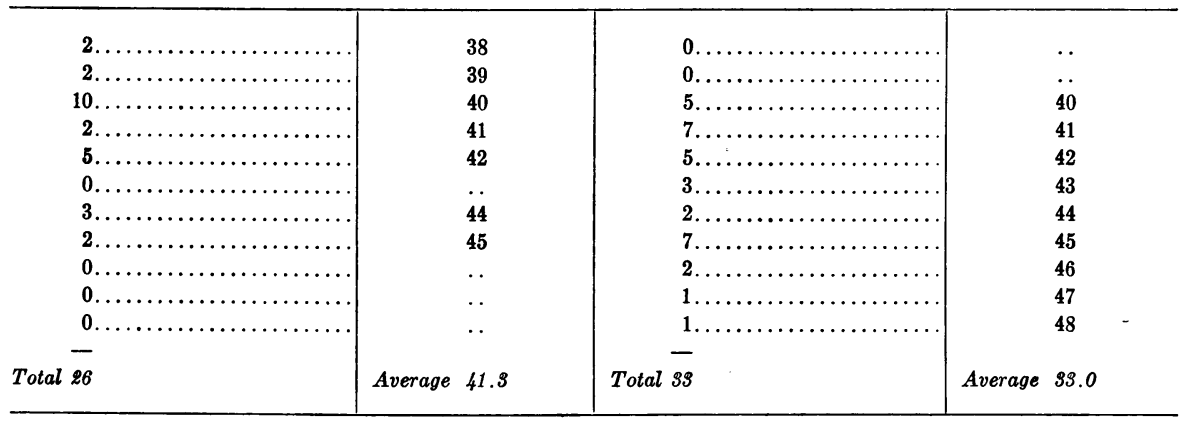

Hatched May 3, and reared on curly-top sugar beets (third experiment)

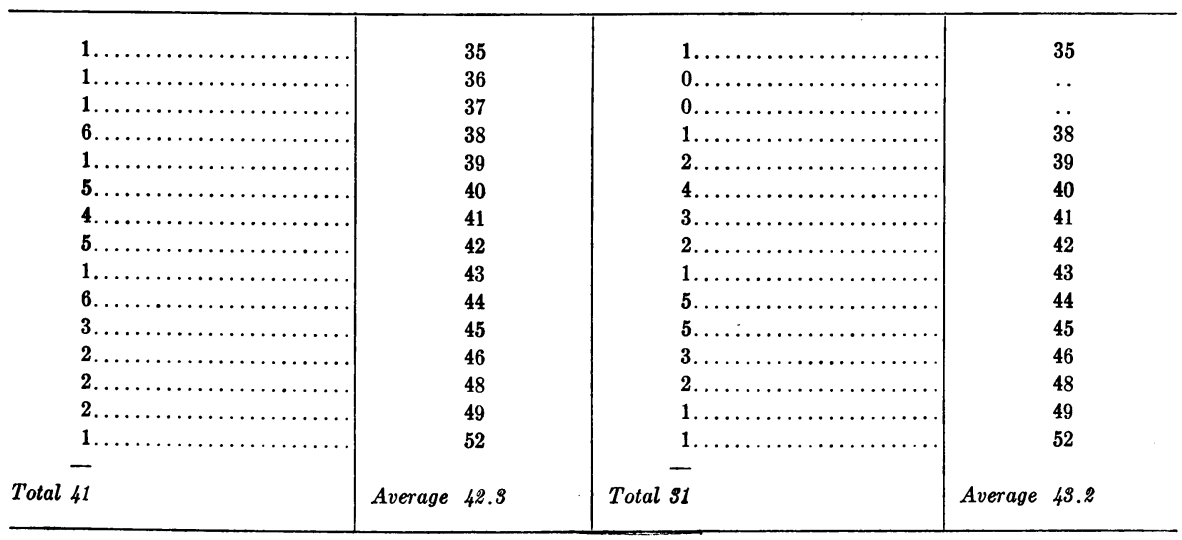


bers of adults were reared, a high mortality of nymphs occurred on healthy celery and more nymphs were reared to the adult stage on diseased than on healthy celery.

The average total duration of the nymphal stages of Texananus spatulatus was less on celery infected with the aster-yellows virus than on healthy plants. The time required for the completion of the nymphal stages on curly-top sugar beets was less than on healthy ones, although this leafhopper is not a vector of the curly-top virus.

A statistical analysis of the data on the duration of the nymphal stages of each adult Texananus lathropi and $T$. spatulatus showed no significance.

There was no evidence to show that the total duration of the nymphal stages of the beet leafhopper, Eutettix tenellus, is shorter on curly-top sugar beets than on healthy plants.

\section{ACKNOWLEDGMENTS}

Grateful acknowledgments are due to R. Craig and W. M. Hoskins for the statistical analysis of the data on the comparison of the duration of the nymphal stages of Texananus lathropi and T. spatulatus. 


\section{LITERATURE CITED}

Carter, W.

1939. Populations of Thrips tabaci, with special reference to virus transmission. Jour. Animal Ecology 8(2):261-71.

KUNKeL, L. $O$.

1926. Studies on aster yellows. [Reprinted from Amer. Jour. Bot. 13:646-705. 1926.] Boyce Thompson Inst. Contrib. 1:181-240.

1932. Celery yellows of California not identical with the aster yellows of New York. Boyce Thompson Inst. Contrib. 4:405-14.

LEACH, J. G.

1940. Insect transmission of plant diseases. 615 p. McGraw-Hill Book Company, New York, N. Y.

SEVERIN, H. H. P.

1921. Minimum incubation periods of causative agent of curly leaf in beet leafhopper and sugar beet. Phytopathology 11(10):424-29.

1928. Transmission of tomato yellows, or curly top of the sugar beet by Eutettix tenellus (Baker). Hilgardia 3(10):251-75.

1929. Yellows disease of celery, lettuce, and other plants, transmitted by Cicadula sexnotata (Fall.). Hilgardia 3(18):543-83.

1934. Transmission of California aster and celery-yellows virus by three species of leafhoppers. Hilgardia 8(10):339-63.

1940. Potato naturally infected with California aster yellows. Phytopathology 30(12): 1049-51.

1942. Infection of perennial delphiniums by California aster-yellows virus. Hilgardia $14(8): 411-30$.

1945. Evidence of nonspecific transmission of California aster-yellows virus by leafhoppers. Hilgardia 17(1):21-59.

Severin, H. H. P., and C. F. Henderson.

1928. Some host plants of curly top. Hilgardia 3(13):339-93. 

PLATE 


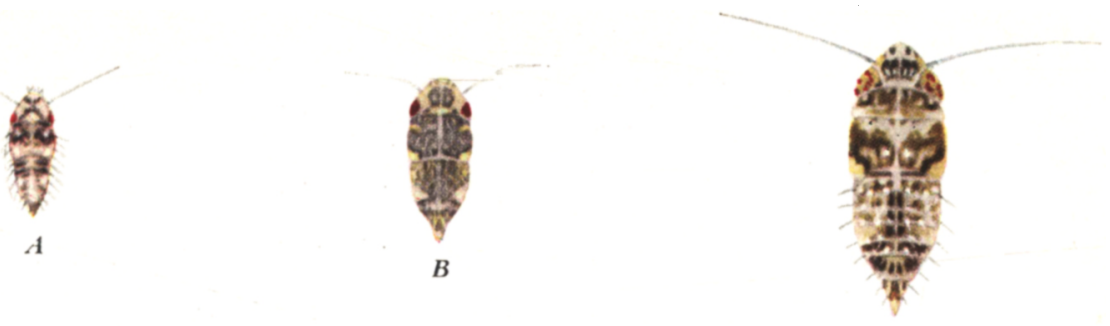

C
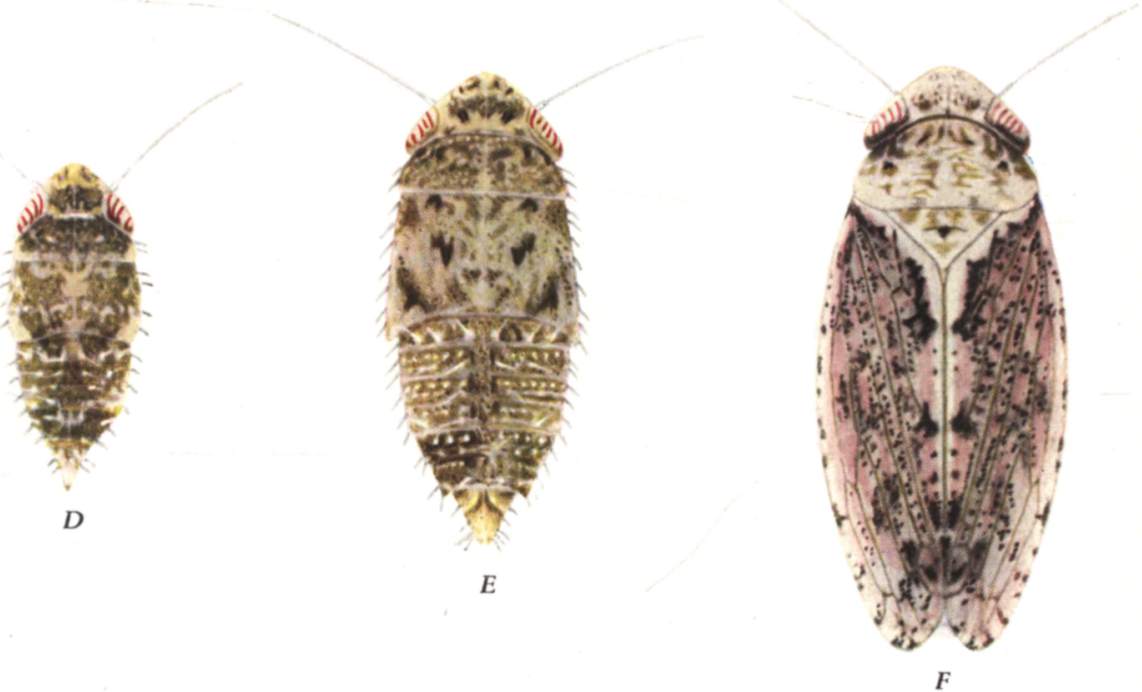

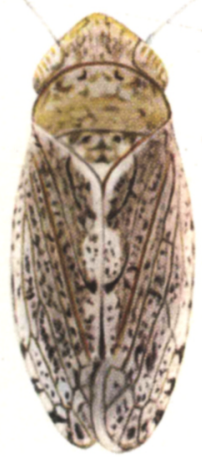

G
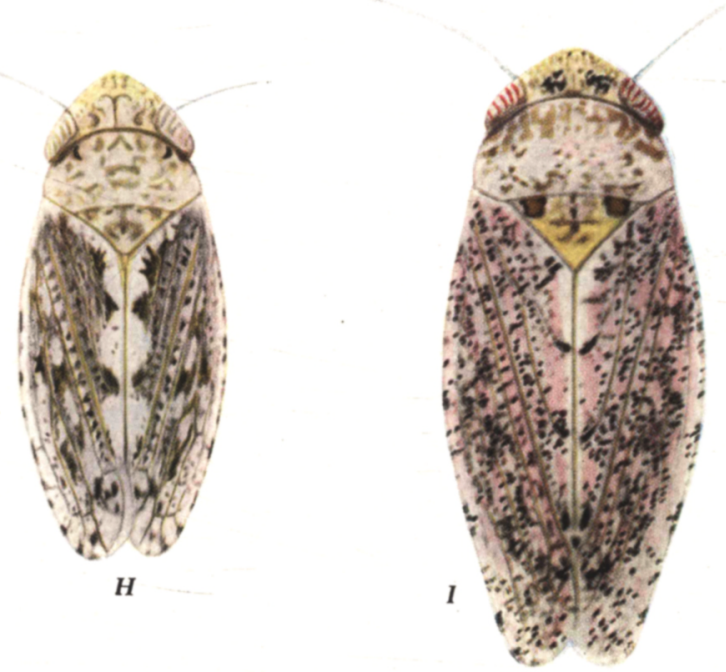

Plate 1.-Color patterns of nymphal instars and adults of Texanamus lathropi Osborn and Lathrop: $A, B, C, D, E$, first to fifth nymphal instars respectively; $G$, male, and $H$, female. $F$, Male, and $I$, female of $T$. denticulus Osborn and Lathrop. 